UDC: $577.35+577.352+576.311$

\title{
EFFECT OF THIAZOLE DERIVATIVE COMPLEXED WITH NANOSCALE POLYMERIC CARRIERS ON CELLULAR ULTRASTRUCTURE OF MURINE LYMPHOMA CELLS IN VIVO
}

\author{
M. V. Popovych ${ }^{\circledR 1}$, Ya. R. Shalai®1*, V. P. Hreniukh ${ }^{\circledR 1}$, O. R. Kulachkovskyy ${ }^{\circledR 1}$, \\ S. M. Mandzynets ${ }^{\mathbb{1} 1}$, N. E. Mitina ${ }^{\circledR 2}$, O. S. Zaichenko ${ }^{\circledR 2}$, A. M. Babsky \\ ${ }^{1}$ Ivan Franko National University of Lviv, 4 Hrushevskyi St., Lviv 79005, Ukraine \\ ${ }^{2}$ Lviv Polytechnic National University, 9 Yura Sqr., Lviv 79013, Ukraine \\ *Corresponding author e-mail: Yaryna.Shalay@Inu.edu.ua
}

Popovych M.V., Shalai Ya.R., Hreniukh V.P., Kulachkovskyy O.R., Mandzynets S.M., Mitina N.E., Zaichenko O.S., Babsky A.M. Effect of thiazole derivative complexed with nanoscale polymeric carriers on cellular ultrastructure of murine lymphoma cells in vivo. Studia Biologica, 2021; 15(2): 15-24 • DOI: https://doi.org/10.30970/sbi.1502.653

Background. A pronounced cytotoxic action of the thiazole derivatives complexed with polymeric carriers on tumor cells in vitro was reported earlier, while no cytotoxicity of these compounds was detected toward noncancerous cells. It was found that thiazole derivatives at concentrations of 10 and $50 \mu \mathrm{M}$ affected lymphoma cell ultrastructure in vitro. The purpose of this work was to investigate the effect of thiazole derivative 8-methyl-2-Me-7-[trifluoromethyl-phenylmethyl]-pyrazolo-[4,3-e]-[1,3]- thiazolo-[3,2-a]pyrimidin-4(2H)-one (PP2) and its complexes with polymeric carriers poly(VEP-coGMA)-graft-mPEG (Th12) and poly(PEGMA) (Th14) on the ultrastructure of lymphoma cells in vivo.

Materials and Methods. Experiments were conducted on white wild-type male mice with grafted NK/Ly lymphoma. Ascite tumors were created by intreperitoneal inoculation of 1-2 mln of Nemet-Kelner lymphoma cells to mice. On the 12th day after inoculation, the body weight of animals was increased by 140-160 \% mostly due to ascites growth. For treatment of ascites three solutions of the chemical compounds were prepared: PP2, PP2 + Th12, PP2 + Th14 and administered to the mice intraperitoneally for 5 days. The final concentration of PP2 was $5 \mathrm{mg} / \mathrm{kg}$ of body weight. Abdominal drainage from ascites was performed with a sterile syringe under chloroform anesthesia on the 10th day after the start of treatment. The ultrastructure of the cells was examined by electron microscopy.

(C) 2021 M. V. Popovych et al. Published by the Ivan Franko National University of Lviv on behalf of Біологічні Студії / Studia Biologica. This is an Open Access article distributed under the terms of the Creative Commons Attribution License (http://www.budapestopenaccessinitiative.org and Creative Commons Attribution 4.0 License), which permits unrestricted reuse, distribution, and reproduction in any medium, provided the original work is properly cited.

ISSN 1996-4536 (print) • ISSN 2311-0783 (on-line) • Біологічні Студії / Studia Biologica • 2021 • Том 15 / № 2 • С. 15-24 
Results. Electron microscopy study showed that control lymphoma cells have a special subcellular formations such as a relatively large nucleus, and specific plasma membrane filaments. The effects of thiazole derivative revealed apoptotic and necrotic manifestations of cytotoxicity, such as a deformation and disintegration of nucleus, a decreased nucleus/cytoplasm ratio, a destruction of the plasma membrane and a change of mitochondria shape. The studied compound complexed with polymeric carriers caused an apoptotic-like changes in lymphoma cells. Under the action of such complexes, the nucleus/cytoplasm ratio decreased and the area of mitochondria increased.

Conclusions. The obtained results suggest that the tested compounds induce apoptosis in tumor cells. Complexes of thiazole derivative with polymers do not impair the effect of the compound on lymphoma cells. The obtained data can be used to carry out further preclinical studies of thiazole derivatives complexed with polymeric carriers as potential antitumor drugs.

Keywords: lymphoma, thiazole derivative, polymeric carriers, cellular ultrastructure, mitochondria

\section{INTRODUCTION}

Despite the undeniable success in treatment and clinical trials, cancer is becoming an increasingly widespread disease and one of the leading causes of mortality worldwide. Chemotherapy is the most commonly used approach in cancer treatment, however it still has a lot of disadvantages such as drug toxicity, low specificity and targeting approach, development of multidrug resistance, rapid degradation of drugs, etc. Therefore, development of new antitumor compounds and eliminating negative effects of current drugs are necessary for successful antitumor therapies.

Thiazole derivatives are widely used as anticancer agents with high efficacy for different types of tumor. It was found that these derivatives cause cytotoxic effects on some lines of tumor cells associated with a lipid peroxidation and superoxide radicals in vitro [13]. As has been previously reported, thiazole derivatives inhibit cancer cell growth and proliferation through a variety of mechanisms, leading to apoptosis orland necrosis of tumor cells [2, 3, 14].

One of the main hurdles for using thiazole derivatives is their poor solubility in water, which significantly reduces their efficacy. In recent years, nanotechnology as an alternative approach to the solvent-based drug solubilization is becoming more and more popular [9]. Except improving the common solubility, nanocarriers have several additional advantages such as an enhanced accumulation in a tumor, targeted delivery, a decreased systemic toxicity and an improved therapeutic effectiveness of antitumor drugs [16]

Polymeric nanocarriers are the most capable drug delivery platforms for anticancer drugs based on their ability to enhance biocompatibility, biodegradability and more effective drug delivery compared with other delivery platforms $[1,5,10]$. Polyethylene glycol (PEG) is a non-ionic compound widely used as a drug carrier because it is soluble in both organic and hydrophilic solvents. Previously, antitumor hydrophobic drugs that were conjugated with PEG showed increasing solubility of drugs and prolongation of the circulation time in an organism [10]. A high anticancer efficiency of polymeric nanocarriers for delivery of doxorubicin and 4-thiazolidinone derivatives to inhibit growth capacity

ISSN 1996-4536 (print) • ISSN 2311-0783 (on-line) • Біологічні Студії / Studia Biologica • 2021 • Том 15 / № 2 • C. 15-24 
and survival of tumor cells in vitro and in vivo was reported [7, 15]. Also, it was shown that PEG- based nanoparticles could be effectively delivered into tumor cells and induce cell necrosis, apoptosis and exhibite higher growth inhibition than free drugs [11]. It was demonstrated, that thiazole derivative 8-methyl-2-Me-7-[trifluoromethyl-phenylmethyl]pyrazolo-[4,3-e]-[1,3]- thiazolo-[3,2-a]-pyrimidin-4(2H)-one (PP2) conjugated with novel polymeric carriers based on PEG increased the toxic action towards tumor cells [4].

The purpose of this work was to investigate the effect of thiazole derivative PP2 conjugated with nanoscale polymer carriers synthesized on the basis of poly(VEP-coGMA)-graft-mPEG (Th12), poly(PEGMA) (Th14) on the ultrastructure of lymphoma cells in vivo.

\section{MATERIALS AND METHODS}

Experiments were conducted on white wild-type male mice (20-30 g) with grafted NK/Ly lymphoma. Animals were kept in standard vivarium conditions at constant temperature on a mixed ration. All manipulations with animals were conducted in accordance with General Ethical Principles of Experimentation on Animals approved by the First National Congress on Bioethics (Kyiv, Ukraine, 2001) and the European Convention for the Protection of Vertebrate Animals used for Experimental and Other Scientific Purposes (Strasbourg, France, 1985), as well as approved by the Ethics Committee of Ivan Franko National University of Lviv, Ukraine (Protocol No. 20-05-2021 of May 18, 2021).

Ascites tumor cells were passaged by intraperitoneal inoculation of $10-15 \times 10^{6}$ cells to mice. Three solutions of the chemical compounds were prepared: PP2 (10 mM), PP2 $(10 \mathrm{mM})+$ Th12 $(1 \mathrm{~g} / 100 \mathrm{~mL})$, PP2 $(10 \mathrm{mM})+$ Th14 $(1 \mathrm{~g} / 100 \mathrm{~mL})$ and administered to the mice intraperitoneally for 5 days. The final concentration of PP2 was $5 \mathrm{mg} / \mathrm{kg}$ of body weight. Ascites was drained from the abdominal cavity of anaesthetized mice with sterile syringe on 7-10 day after the inoculation. Lymphoma cells were washed in $0.2 \mathrm{~mol} / \mathrm{L}$ cacodylate buffer and fixed in a solution containing $1.5 \%$ glutaraldehyde in the cacodylate buffer for $2 \mathrm{~h}$ and $1 \%$ solution of osmium tetroxide $(2 \mathrm{~h})$ in the same buffer. Subsequently, the specimens were transferred into a $1.5 \%$ aqueous uranyl acetate solution for $12 \mathrm{~h}$. the fixed specimens were washed and dehydrated at room temperature at concentrations of ethanol from 70 to $100 \%$. The dehydrated specimens were placed into pure epoxy resin for $48 \mathrm{~h}$ at 40 and $60{ }^{\circ} \mathrm{C}$. Microscopic sections were cut on a UTMP6 ultramicrotome; then, the specimens were contrasted with a $1.5 \%$ solution of uranylacetate (prepared in $70 \%$ ethanol) and photographed using a PEM100 transmission electron microscope (Electron-SELMI, Ukraine) [6]. The thiazole derivative (PP2) was synthesized at the Department of Organic Chemistry of Ivan Franko National University of Lviv. The PEG-containing carriers (poly(VEP-co-GMA)-graft-mPEG (Th12), poly(PEGMA) (Th14)) were synthesized at the Department of Organic Chemistry of Lviv Polytechnic National University. The steps of synthesis were described in detail in our previous publications [3, 4].

On the basis of electronic microphotographs $(n=60)$, using computer program ImageJ the following data were calculated: the relation of the nucleus and cytoplasm area, the ratio of the area of nucleus and cytoplasm (N/C ratio), the number and area of mitochondria, the number and area of lysosomes. Besides, a qualitative assessment of the form of cells, nuclei, mitochondria and their christs was made. Statistical analysis of the obtained results was carried out using the MS Excel-2013 and Statistica programs.

ISSN 1996-4536 (print) • ISSN 2311-0783 (on-line) • Біологічні Студії / Studia Biologica • 2021 • Том 15 / № 2 • С. 15-24 
To assess the reliability of difference between statistical characteristics of two alternative sets of data, Student's coefficient and Kruskal-Wallis test were calculated. The difference was considered to be significant at $P<0.05$.

\section{RESULTS AND DISCUSSION}

Qualitative analysis of pictures of control Nemet-Kelner lymphoma (NK/Ly) cells showed that the nucleus (2) takes up a large part ( $40 \%)$ of the cell area (Fig. 1). High nucleus-cytoplasm ratio is typical for tumor cells where intensive synthetic and proliferative processes occur. Well notable nucleolus (3) and mitochondria (4) of different sizes and shapes are present. The mitochondrial matrix is electronically dense. In addition, there are a number of high-density lysosomes localized in the cytoplasm (5) (Fig. 1).
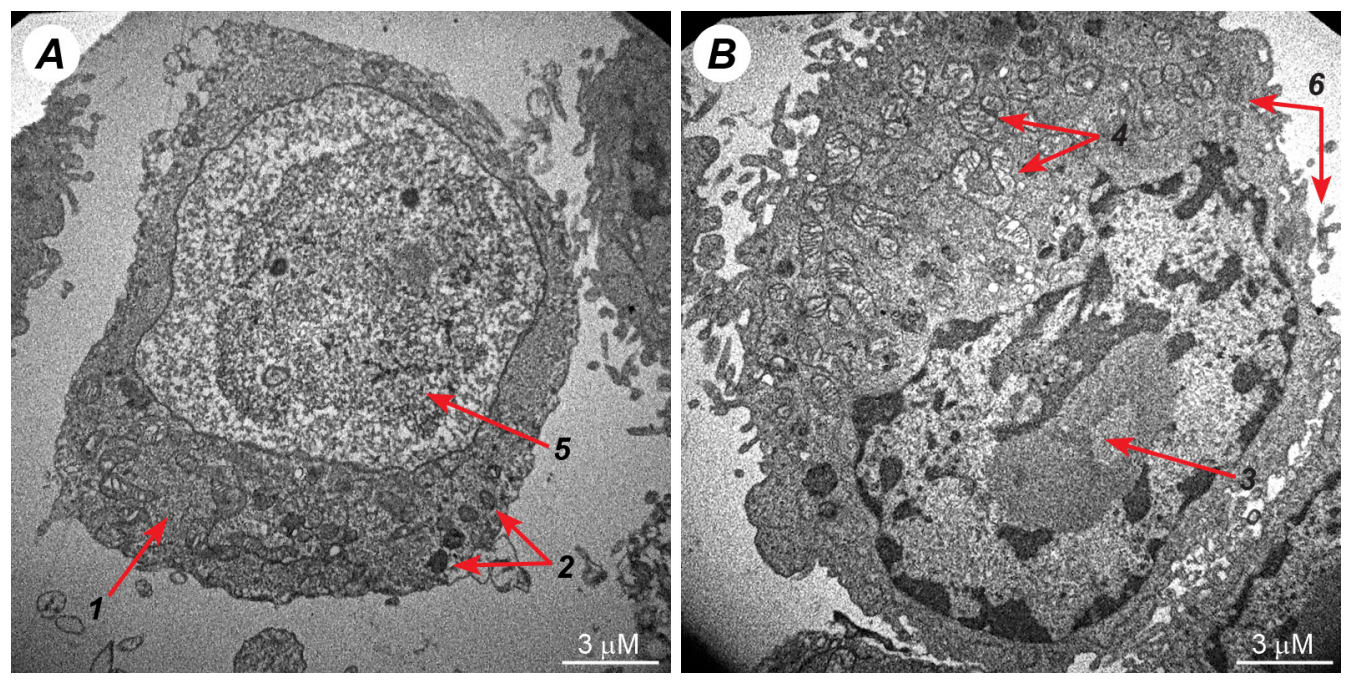

Fig. 1. Representative electronic microscopy pictures of two lymphoma NK/Ly untreated cells. The arrows point to: 1 - cytoplasm; 2 - nucleus; 3 - nucleolus; 4 - mitochondria; 5 -lysosomes, 6 - buds of the plasma membrane

Рис. 1. Типові електронно-мікроскопічні зображення двох контрольних клітин лімфоми NK/Ly. Cтрілками позначено: 1 - цитоплазма; 2 - ядро; 3 - ядерце; 4 - мітохондрії; 5 - лізосоми; 6 вип'ячування плазматичної мембрани

It was found that PP2 at concentration of $5 \mathrm{mg} / \mathrm{kg}$ causes a decrease in cell size (shrinkage), a deformation and decrease in nucleus size (Fig. 2: A2, B2), and a destruction of plasma membrane (A6, B6). Some mitochondria contain swollen crists (B4), while others contain paralleled crists (A 4).

The complexation of compounds PP2 and polymeric carrier Th12 led to a decrease in the cell area, fragmentation of the nucleus and a decrease in its size (A2; B2), violation of the integrity of the plasma membrane (B6) and changes in the shape of mitochondria (B4) compared with control indicators (Fig. 3).

It was found that Th14 (complex of compound PP2 and polymeric carrier poly(PEGMA)) in a final concentration of $10 \mu \mathrm{m}$ caused a violation of the plasma membrane, the shape of lymphoma cells and causes their reduction, cell nuclei are deformed and reduced in volume (A2, B2), the number mitochondria increase (A4; B4) relative to control (Fig. 4).

ISSN 1996-4536 (print) • ISSN 2311-0783 (on-line) • Біологічні Студії / Studia Biologica • 2021 • Том 15 / № 2 • C. 15-24 

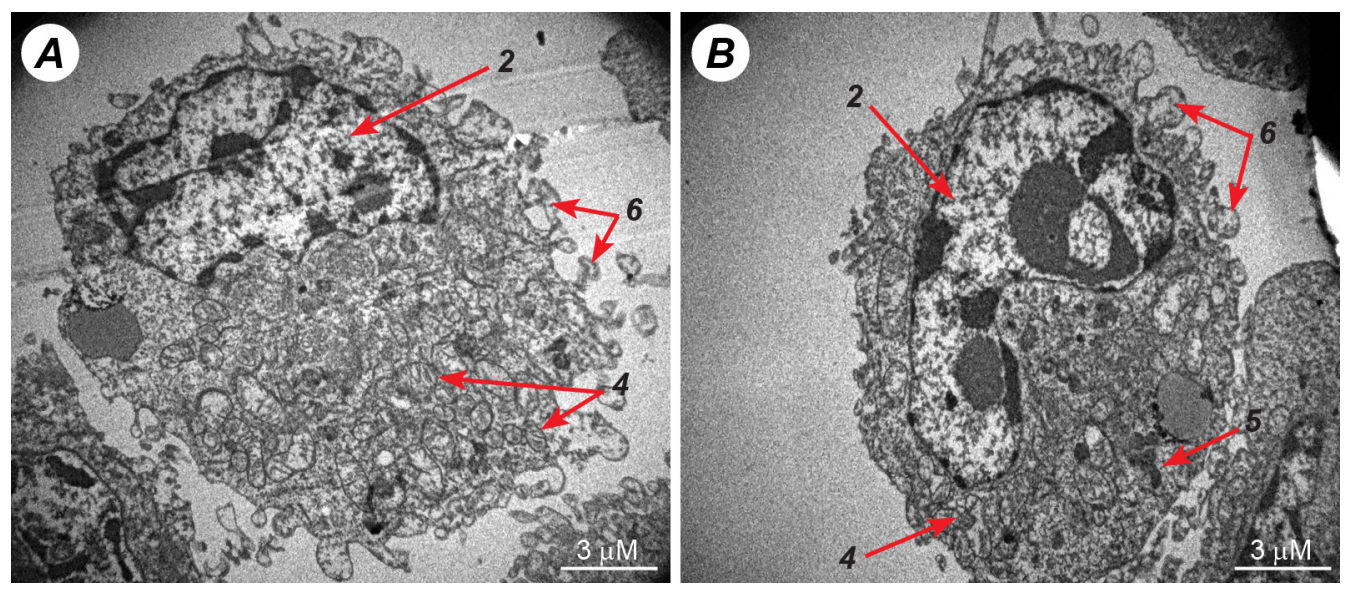

Fig. 2. Representative electronic microscopy pictures of two NK/Ly lymphoma cells under the effect of PP2 at concentration of $5 \mathrm{mg} / \mathrm{kg}$. For further description, see Fig. 1

Рис. 2. Типові електронно-мікроскопічні зображення клітин лімфоми NK/Ly за дії PP2 в концентрації 5 мг/кг. Інші пояснення див. на рис. 1
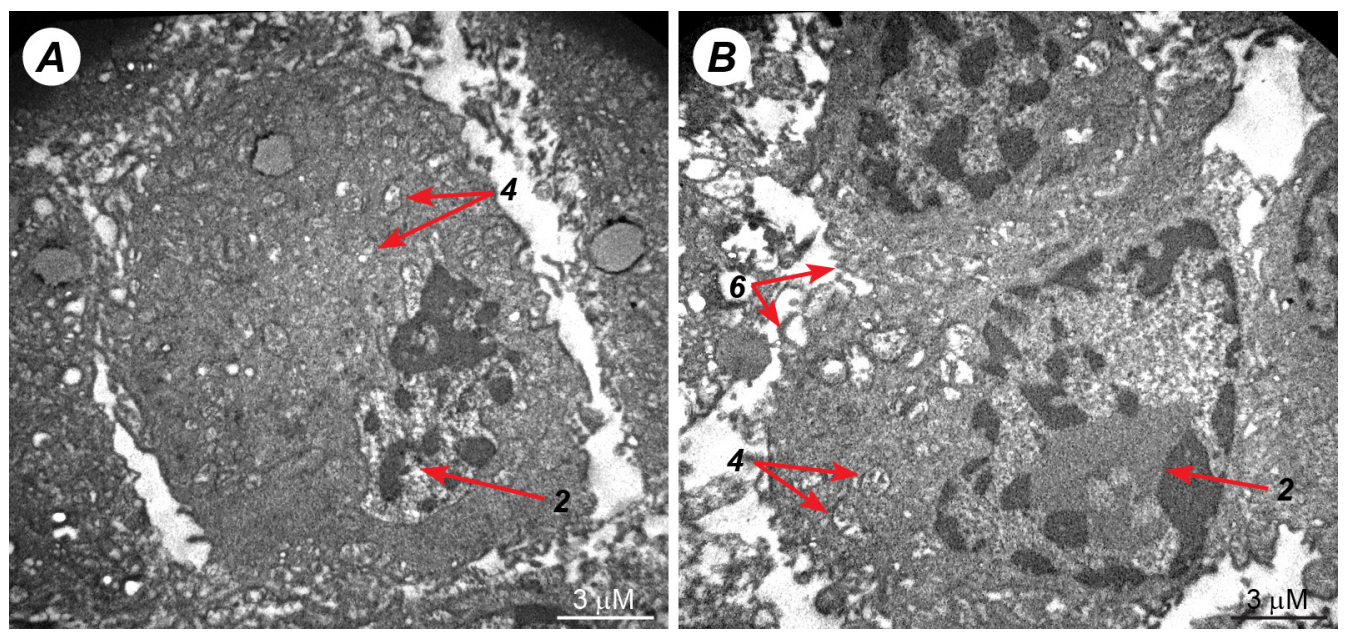

Fig. 3. Representative electronic microscopy pictures of NK/Ly lymphoma cells under the effect of the complex PP2 + Th12. For further description, see Fig. 1 and 2

Рис. 3. Типові електронно-мікроскопічні зображення клітин лімфоми NK/Ly за дії комплексу PP2 + Th12. Інші пояснення див. на рис. 1 і 2

Based on the quantitative analysis of electronic photographs of lymphoma cells, it was determined that the N/C ratio of control NK/Ly cells was 0.72 conventional units (c.u.), while under the influence of PP2 at a concentration of $5 \mathrm{mg} / \mathrm{kg}$, this parameter decreased by $39 \%$ (Student test $-\mathrm{P}=0.03$ ). Complex PP2 + Th14 but not PP2 + Th12 caused a decrease in N/C ratio by $35 \%$ (Student test $-\mathrm{P}=0.017$, Kruskal-Wallis test $P=0.0016)$. The area of the lymphoma cells mitochondria significantly increased by $55 \%$ under the action of PP2 + Th14 (Student test $-P=0.025$, Kruskal-Wallis test $-P=0.05$ ). The area of lysosomes also increased under the action of this complex (Kruskal-Wallis test $-\mathrm{P}=0.05)$ (see Table). 

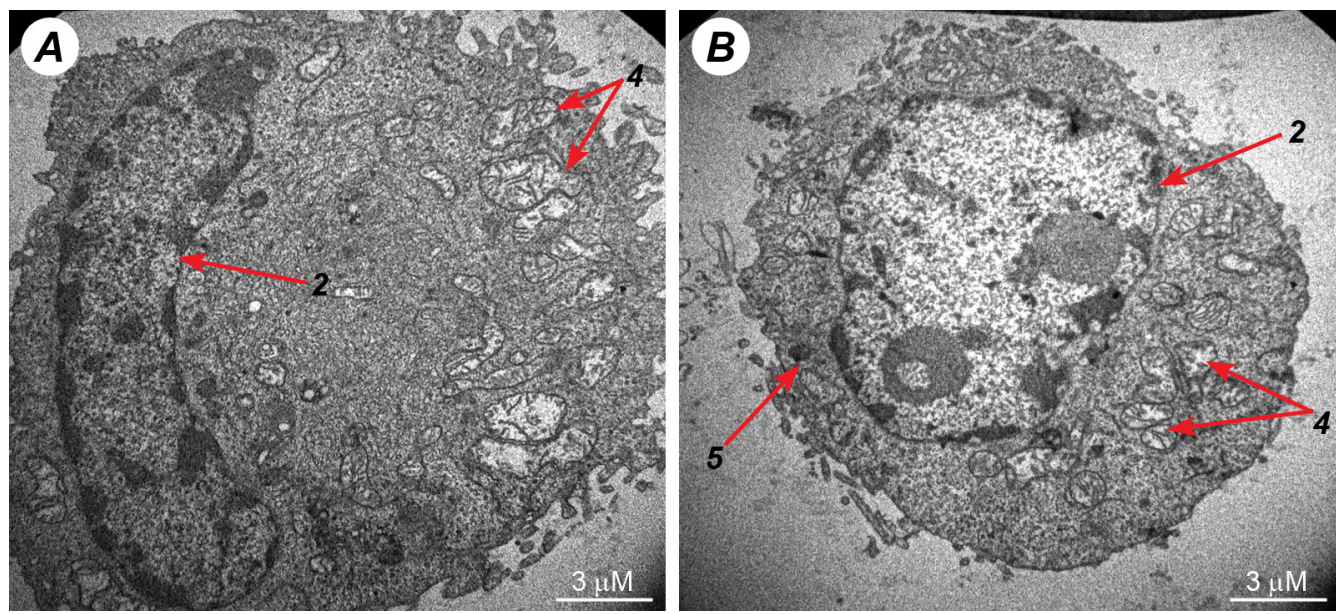

Fig. 4. Electronic microscopy pictures of NK/Ly lymphoma cells under the effect of the complex PP2 + Th14. For further description, see Fig. 1 and 2

Рис. 4. Типові електронно-мікроскопічні зображення за дії комплексу PP2 + Th14. Інші пояснення див. на рис. 1 і 2

\section{A quantitate analysis of the electronic microscopy data of lymphoma cells under the effect of thiazole derivative (PP2) and a complexes of PP2 with polymeric carriers Th12 and Th14 \\ Кількісний аналіз даних електронно-мікроскопічних фотографрій клітин лімфоми за дії похідного тіазолу РP2 \\ і його комплексів із полімерними носіями Th12 і Th14}

\begin{tabular}{|l|l|c|c|c|c|}
\hline No & \multicolumn{1}{|c|}{ Parameters } & Control & PP2 & PP2 + Th12 & PP2 + Th14 \\
\hline & \multicolumn{1}{|c|}{ Number of analyzed cells } & 30 & 10 & 10 & 10 \\
\hline 1 & Nuclear/cytoplasmic ratio (c. u.) & $0.72 \pm 0.36$ & $0.44 \pm 0.21^{*}$ & $0.51 \pm 0.22$ & $0.47 \pm 0.19^{\star * \# \#}$ \\
\hline 2 & Lysosome area (\%) & $100 \pm 11.2$ & $82 \pm 3.2$ & $101 \pm 3.1$ & $131 \pm 2.8 \#$ \\
\hline 3 & Number of lysosomes (per cell) & $8 \pm 2$ & $6 \pm 3$ & $4 \pm 3$ & $7 \pm 2$ \\
\hline 4 & Mitochondria area (\%) & $100 \pm 8.6$ & $117 \pm 5.2$ & $111 \pm 3.2$ & $155 \pm 2.6^{*} \#$ \\
\hline 5 & Number of mitochondria (per cell) & $8 \pm 3$ & $7 \pm 2$ & $8 \pm 3$ & $8 \pm 2$ \\
\hline
\end{tabular}

Comments: Lysosome and mitochondria areas in control groups were taken as $100 \%$. Student test: * $-\mathrm{P} \leq 0.05,{ }^{* *}-\mathrm{P} \leq 0.01$; Kruskal-Wallis test: \# $-\mathrm{P} \leq 0.05$, \#\# - P $\leq 0.01$

Примітки: Площі лізосом і мітохондрій у контрольних групах приймали за $100 \%$.

Тест Стьюдента: * - P $\leq 0,05,{ }^{* *}-\mathrm{P} \leq 0,01$; Тест Крускала-Уолліса: \# - P $\leq 0,05$, \#\# - P $\leq 0,01$

Thus, the investigated PP2 at concentration of $5 \mathrm{mg} / \mathrm{kg}$ in vivo caused visible changes in the ultrastructure of lymphoma cells. The action of the substance led to a deformation of the plasma membrane and nucleus, and to a decrease in the nucleus/ cytoplasmic ratio. These changes are similar to the effect of thiasole derivative (PP2) when lymphoma cells were incubated with the chemical in vitro [14]. We believe that

ISSN 1996-4536 (print) • ISSN 2311-0783 (on-line) • Біологічні Студії / Studia Biologica • 2021 • Том 15 / № 2 • C. 15-24 
these morphological changes are the result of apoptosis-like perturbations, such as an activation of poly (ADP-ribose) polymerase 1 and caspase 3 cleavage, as well as an increase in the level of pro-apoptotic Bim protein and the mitochondrion-specific EndoG nuclease, and a decrease in the level of the anti-apoptotic Bcl-2 protein [3]. Thiazole derivatives also caused DNA single-strand breaks and DNA fragmentation in leukemia cells [2]. We have shown that antiproliferative action of PP2 may be related to a violation of the activity of some enzymes of the antioxidant system (catalase, glutathione-peroxidase) [14].

PP2 complexed with polymeric carriers at concentration of $10 \mu \mathrm{M}$ caused changes of apoptotic type in the ultrastructure of lymphoma cells. Earlier, it was shown that 2-amino-5-benzylthiazole derivative caused necrosis in lymphoma cells in vitro [14]. In this study, necrotic changes in the ultrastructure under the action of the studied substances were not observed, while signs of apoptotic changes were detected. Yang et al. showed that a complex of antitumor compound oxaliplatin with PEG-liposomal carriers induced a stronger apoptotic response than free oxaliplatin [16]. These data indicate that the polymeric carriers improve the delivery of compounds to the cell. Thiazole derivatives complexed with polymeric carriers are characterized by high lipophilicity due to the presence of a macrocycle ring in the molecular structure. This feature facilitates their penetration into the cell and determines intracellular targets [8]. Since it has previously been found that the test compounds do not affect non-tumor cells [4], it can be assumed that they are highly selective for tumors.

\section{CONCLUSION}

Test compounds caused apoptotic changes in the ultrastructure of lymphoma cells. Complexed action of PP2 with polymers do not impair the effect of the substance on the lymphoma cells. Complex Th14 was more effective than complex Th12, because it significantly changed the quantitative indicators of lymphoma cells. Since the tested compounds do not affect normal cells, this thiazole derivative complexed with polymeric carriers might be considered as a potential antitumor drug.

\section{COMPLIANCE WITH ETHICAL STANDARDS}

Conflict of Interest: The authors declare that the research was conducted in the absence of any commercial or financial relationships that could be construed as a potential conflict of interest.

Human Rights: This article does not contain any studies with human subjects performed by any of the authors.

Animal Studies: All institutional, national and institutional guidelines for the care and use of laboratory animals were followed.

1. Avramović N., Mandić B., Savić-Radojević A., Simić T. Polymeric nanocarriers of drug delivery systems in cancer therapy. Pharmaceutics, 2020; 12 (4): 298.

Crossref • PubMed • PMC • Google Scholar

2. Finiuk N., Klyuchivska O., Ivasechko I., Hreniukh V., Ostapiuk Yu., Shalai Ya., Panchuk R., Matiychuk V., Obushak M., Stoika R., Babsky A. Proapoptotic effects of novel thiazole derivative on human glioma cells. Anticancer Drugs, 2019; 1(3): 27-37.

Crossref $\bullet$ PubMed $\bullet$ Google Scholar

ISSN 1996-4536 (print) • ISSN 2311-0783 (on-line) • Біологічні Студії / Studia Biologica • 2021 • Том 15 / № 2 • C. 15-24 
3. Finiuk N.S., Ostapiuk Yu.V., Hreniuh V.P., Shalai Ya.R., Matiychuk V.S., Obushak M.D., Stoika R.S., Babsky A.M. Evaluation of antiproliferative activity of pyrazolothiazolopyrimidine derivatives. The Ukrainian Biochemical Journal, 2018; 90(2): 25-32.

Crossref $\bullet$ Google Scholar

4. Finiuk N.S., Popovych M.V., Shalai Ya.R., Mandzynets' S.M., Hreniuh V.P., Ostapiuk Yu.V., Obushak M.D., Mitina N.E., Zaichenko O.S., Stoika R.S., Babsky A.M. Antineoplastic activity in vitro of 2-amino-5-benzylthiasol derivative in the complex with nanoscale polymeric carriers.

Cytology and Genetics, 2021; 55 (1): 19-27. Crossref $\bullet$ Google Scholar

5. Han J., Zhao D., Li D., Wang X., Jin Z., Zhao K. Polymer-based nanomaterials and applications for vaccines and drugs. Polymers, 2018; 10(1): 31.

Crossref $\bullet$ PubMed $\bullet$ PMC $\bullet$ Google Scholar

6. Kaminskyy V., Kulachkovskyy O., Stoika R. A decisive role of mitochondria in defining rate and intensity of apoptosis induction by different alkaloids. Toxicology Letters, 2008; 177(3): 168-181.

Crossref $\bullet$ PubMed $\bullet$ Google Scholar

7. Kobylinska L.I., Havrylyuk D. Ya., Mitina N.E., Zaichenko O.S., Lesyk R.B., Zimenkovsky B.S., Stoika R.S. Biochemical indicators of nephrotoxicity in blood serum of rats treated with novel 4-thiazolidinone derivatives or their complexes with polyethyleneglycol-containing nanoscale polymeric carrier. The Ukrainian Biochemical Journal, 2016; 88(1): 51-60.

Crossref $\bullet$ PubMed $\bullet$ Google Scholar

8. Mandzynets S.M., Kulachkovskii O.R., Bura M.V. Effect of avermectin on the ultrastructural characteristics of loach embryos. Cytology and Genetics, 2011; 45(5): 318-323. (In Ukrainian)

Crossref $\bullet$ Google Scholar

9. Mulik R.S., Mönkkönen J., Juvonen R.O., Mahadik K.R., Paradkar A.R. Apoptosis-induced anticancer effect of transferrin-conjugated solid lipid nanoparticles of curcumin. Cancer Nanotechnology, 2012; 3(1-6): 65-81.

Crossref $\bullet$ PubMed $\bullet$ PMC $\bullet$ Google Scholar

10. Nath Roy D., Goswami R., Pal A. Nanomaterial and toxicity: what can proteomics tell us about the nanotoxicology? Xenobiotica, 2017; 47(7): 632-43.

Crossref $\bullet$ PubMed $\bullet$ Google Scholar

11. Pei X., Zhou Z., Gan Z., Chen J., Zhang X., Cheng X., Wan Q., Wang J. PEGylated nanographene oxide as a nanocarrier for delivering mixed anticancer drugs to improve anticancer activity. Scientific Reports, 2020; 10(1): 2717.

Crossref $\bullet$ PubMed $\bullet$ PMC $\bullet$ Google Scholar

12. Shalai Ya.R., Mandzynets S.M., Finiuk N.S., Hreniukh V.P., Babsky A.M. Processes of lipoperoxidation and respiration of mitochondria in the rat liver under the action of thiazoles derivatives in vitro. Studia Biologica, 2018; 12(2): 35-44.

Crossref $\bullet$ Google Scholar

13. Shalai Ya.R., Mandzynets S.M., Hreniukh V.P., Finiuk N.S., Babsky A.M. Free-radical processes in NK/Ly lymphoma cells and hepatocytes under the effect of thiazole derivative. Bulletin of problems biology and medicin, 2018; 1.2(143): 234-238.

Crossref

14. Shalai Ya.R., Popovych M.V., Kulachkovskyy O.R., Hreniukh V.P., Mandzynets S.M., Finiuk N.S., Babsky A.M. Effect of novel 2-amino-5-benzylthiazole derivative on cellular ultrastructure and activity of antioxidant system in lymphoma cells. Studia Biologica, 2019; 13(1): 51-60.

Crossref $\bullet$ Google Scholar

ISSN 1996-4536 (print) • ISSN 2311-0783 (on-line) • Біологічні Студії / Studia Biologica • 2021 • Том 15 / № 2 • C. 15-24 
15. Senkiv Y., Riabtseva A., Heffeter P., Boiko N., Kowol C.R., Jungwith U., Shlyakhtina Y., Garasevych S.G., Mitina N., Berger W., Zaichenko O., Stoika R. Enhanced anticancer activity and circumvention of resistance mechanisms by novel polymeric/phospholipidic nanocarriers of doxorubicin. Journal of Biomedical Nanotechnology, 2014; 10(7): 1369-1381.

Crossref $\bullet$ PubMed $\bullet$ Google Scholar

16. Yang C., Liu H.-Z., Fu Z.-X. Effects of PEG-liposomal oxaliplatin on apoptosis, and expression of cyclin A and cyclin D1 in colorectal cancer cells. Oncology Reports, 2012; 28(3): 1006-1012.

Crossref • PubMed • Google Scholar

17. Wang L., Du J., Zhou Y., Wang Y. Safety of nanosuspensions in drug delivery. Nanomedicine: Nanotechnology, Biology and Medicine, 2017; 13(2): 455-469.

Crossref $\bullet$ PubMed $\bullet$ Google Scholar

\title{
ВПЛИВ ПОХІДНОГО ТІАЗОЛУ В КОМПЛЕКСІ 3 НАНОРОЗМІРНИМИ ПОЛІМЕРНИМИ НОСІЯМИ НА УЛЬТРАСТРУКТУРУ КЛІТИН ЛІМФОМИ IN VIVO
}

\author{
М. В. Попович 1 , Я. Р. Шалай ${ }^{1 *}$, В. П. Гренюх ${ }^{1}$, О. Р. Кулачковський ${ }^{1}$ \\ С. М. Мандзинець ${ }^{1}$, Н. Є. Мітіна ${ }^{2}$ О. С. Заїченко ${ }^{2}$, А. М. Бабський \\ 1 Львівський національний університет імені Івана Франка \\ вул. Грушевського, 4, Львів 79005, Україна \\ ${ }^{2}$ Націона́льний університе́m "Львівська політе́хніка" \\ пл. Святого Юра, 9, Львів 79013, Україна \\ *Кореспондуючий автор e-mail: Yaryna.Shalay@Inu.edu.ua
}

Обґрунтування. Раніше встановлено виражену цитотоксичну дію похідних тіазолу в комплексі з полімерними носіями на клітини пухлин in vitro. Ці сполуки не були цитотоксичними щодо неракових клітин. Встановлено, що похідні тіазолу в концентраціях 10 і 50 мкМ впливали на ультраструктуру клітин лімфоми in vitro. Мета роботи полягала у дослідженні впливу комплексу похідного тіазолу 8-methyl2-Me-7-[trifluoromethyl-phenylmethyl]-pyrazolo-[4,3-e]-[1,3]-thiazolo-[3,2-a]-pyrimidin4(2H)-one (PP2) іполімерних носіїв poly(VEP-co-GMA)-graft-mPEG (Th12) i poly(PEGMA) (Th14) на ультраструктуру клітин лімфоми in vivo.

Матеріали та Методи. Експерименти виконували на білих мишах самцях дикого типу з прищепленою лімфомою NK/Ly. Клітини пухлини прищеплювали мишам внутрішньочеревно. Розчин сполук PP2, PP2 + Th12, PP2 + Th14 і вводили мишам внутрішньочеревно протягом 5 днів. Розчин вводили мишам внутрішньочеревно у кінцевій концентрації РP2 5 мг/кг маси тіла протягом 5 днів. Дренаж черевної порожнини проводили стерильним шприцом під анестезією на 10-й день від початку лікування. Ультраструктуру клітин лімфоми досліджували за допомогою електронної мікроскопії.

Результати. Дані електронної мікроскопії виявили, що клітини контрольної лімфоми мають особливості, притаманні пухлинним клітинам: відносно велике ядро, високе співвідношення площі ядра до площі цитоплазми і специфічні вирости плазматичної мембрани. Встановлено, що за дії похідного тіазолу in vivo у клітинах лімфоми виникають переважно апоптотичні зміни, такі як деформація та руйнування ядра, зменшення ядерно-цитоплазматичного співвідношення, руйнування плазматичної мембрани та зміна форми мітохондрій. За спільної дії РP2 і полімер-

ISSN 1996-4536 (print) • ISSN 2311-0783 (on-line) • Біологічні Студії / Studia Biologica • 2021 • Том 15 / № 2 • C. 15-24 
ного носія Th14 достовірно збільшувалася площа мітохондрій і лізосом, що опосередковано може вказувати на активацію мітохондріального механізму апоптозу або клітинної автофагії.

Висновки. Ці результати дають підстави вважати, що досліджувані сполуки реалізують свою цитотоксичну дію через індукування апоптозу в пухлинних клітинах. Полімерні носії у комплексі з досліджуваною речовиною посилювали деструктивні зміни у клітинах лімфоми. Отримані дані можуть бути використані для подальших доклінічних досліджень похідних тіазолу в комплексі з полімерними носіями як потенційними протипухлинними препаратами.

Ключові слова: лімфома, похідне тіазолу, полімерні носії, ультраструктура клітини, мітохондрії 